\title{
Properties and biological activity of rainfed gray soils formed in neogenic slopes in Uzbekistan
}

\author{
Gulzira Raimbaeva ${ }^{1 *}$ and Gulmira Mirkhaydarova ${ }^{1}$ \\ ${ }^{1}$ Tashkent State Agrarian University, University str., 2, Tashkent province, 100174 Uzbekistan
}

\begin{abstract}
In Uzbekistan, along with gray soils formed in lyoss deposits, reddish soils formed in Neogene deposits are also widespread, which are distributed in mountainous and foothill areas. Reddish soils differ from gray soils formed in lyoss deposits by their appearance, genesis, and properties. The reddish-gray soils formed in the Neogene deposits are widespread in many parts of Uzbekistan and are subject to various levels of erosion. The reddish-brown soils formed in the Neogene deposits are mainly formed in the parent rocks that form a homogeneous lyoss soil, in some places these layers are very shallow and in the strata occur tertiary and calcareous loams, sands and conglomerates. The reddish-gray soils formed in the Neogene deposits are eroded to varying degrees as they are spread on different levels of slope. Erosion damages the fertile layer on the surface of the soil and reduces its fertility. Eroded soils are washed to varying degrees. Under the influence of the erosion process, the amount of humus and nutrients in the soil decreases sharply. Erosion processes adversely affect the mechanical composition, physical, agrochemical properties and biological activity of the soil. As a result, soil fertility decreases. For the soil to be fertile, it is necessary to maintain and increase the amount of humus and nutrients in it.
\end{abstract}

\section{Introduction}

It is important to study the genesis, morphological features, mechanical composition, physical and agrochemical properties, the importance of biological and biochemical processes in soil fertility of reddish gray soils formed in Neogene deposits [1, 2]. Organic residues of plants and various microorganisms in the soil are broken down under the influence of microelements, microbiological, biological and biochemical processes in it, and organic matter accumulates in the soil. The activity of biological processes in the soil is important in the growth and development of plants. Enzymes play a very important role in the formation of nitrogen and phosphorus in the soil in the course of various chemical and biochemical reactions in the soil [2-4].

The amount of micronutrients in rainfed gray soils formed in Neogene deposits, the effect of erosion processes on them, the interaction of micronutrients with enzymes, the activity of urease and protease enzymes in the soil vary depending on the season. Protease-

\footnotetext{
* Corresponding author: gulmira sulton@mail.ru
} 
enzyme is an enzyme necessary for the formation and metabolism of nitrogen in the soil and is actively involved in the formation and breakdown of proteins [5-7].

The activity of the protease and urease enzyme in the studied soils is significantly reduced in winter and summer. In reddish gray soils, the enzyme protease and urease are mainly found in greater amounts in the upper humus layers of the soil [7]. After $50 \mathrm{~cm}$ in the lower layers of the soil, the activity of the protease and urease enzyme decreases sharply. Protease and urease enzymes in non-eroded soils are higher than in eroded soils. The activity of the enzyme protease and urease in the upper layers of non-eroded gray soils is also higher in spring than in fall $[7,8]$.

Micronutrients in the soil are part of the enzymes necessary for plant growth and development, helping to accelerate their activity [9]. Accelerates the process of photosynthesis, ensures the formation of nucleic acids, proteins and carbohydrates in the plant body. The level of exposure to micronutrients is manifested in a very short range, the lack of which adversely affects the growth, development and productivity of the plant $[9$, $10]$.

Increasing the mobility of copper in the soil is caused by an increase in the concentration of hydrogen ions in the soil, the application of nitrogen physiological fertilizers, mineralization of organic matter by microorganisms, the accumulation of ammonium and nitrate in the soil $[3,10]$.

The activity of the enzymes urease, phosphatase and catalase in soils formed in Neogene deposits and the effect of erosion on them were studied [1,2]. The studies compared the properties and biological activity of rainfed gray soils formed in lyoss and Neogene deposits. The data show that the biogenicity of the soil depends on the vegetation cover on the soil surface, the amount of humus, the mechanical composition of the soil, the soil environment, soil properties, the amount of trace elements and enzyme activity [4-8].

The study of soil genesis, properties, biological and biochemical processes is important in maintaining and increasing soil fertility. Enzymes play an important role in the conversion and decomposition of organic matter, in the formation of humic substances. The main sources of enzymes are living organisms living in the soil, bacteria, actinomycetes, invertebrates and plants. Enzymes in the soil are actively involved in the conversion of organic residues. Enzymes as catalysts accelerate the decomposition and synthesis of organic matter up to a million times [10-12]. All enzyme complexes in the soil determine the enzymatic activity of the soil. The biological activity of the soil is directly related to the organic matter in the soil.

\section{Materials and methods}

The soils of the studied area are reddish rainfed gray soils formed in the Neogene deposits, distributed in the foothills of the Western Tien Shan and on the right bank of the Chirchik River. In this area, reddish-gray loamy soils formed in the Neogene deposits of the Tertiary period are distributed, consisting of reddish sediments. Research was carried out on the reddish-gray soils formed in the Neogene deposits of the Tertiary period in the open soils of the village of May, Qibray district of Tashkent province, Uzbekistan.

Climatic conditions of the region, where the gray soils formed in the Neogene deposits are distributed, are located in the Turan lowlands of the Central Asian region, with sharply changing subtropical climatic conditions. The reddish soils formed in the Neogene deposits are rainfed gray soils in the village of May, Qibray district, Tashkent region, the geographical location of which is associated with atmospheric circulation, drought of solar radiation, high heat and continental. The change in climatic conditions depending on the seasons is that spring is humid and short-lived, dry and hot. As getting closer to the 
mountains, the slopes of the foothills increase and the plains are replaced by river valleys, streams and ravines and located in the foothills.

The annual rainfall is $399-422 \mathrm{~mm}$, with heavy rainfall in fall, winter and early spring. The vegetation period for plants is $204-234$ days. Summer is $+39.7+45.8{ }^{\circ} \mathrm{C}$ in July, and $11.3-11.7{ }^{\circ} \mathrm{C}$ in December and January. The effective heat sum is $2220-2450{ }^{\circ} \mathrm{C}$ [13].

The reddish-gray soils formed in the Neogene deposits are distributed in the middle part of the area, in the much higher part of the foothills. These soils are located at an altitude of 500-700 to 1000-1200 meters above sea level. The relief of the region consists of steep slopes. The relief is uneven. The soils are lyoss, covered with reddish soils formed in Tertiary Neogene deposits [13].

The plants of the foothills consist of grasses such as ephemeral and ephemeroids, the most common plants, such as lilac and carnation. Along with ephemeroids grow ephemerals such as chamomile (Lagia), lily (Lxioliron), pea (Astra alia), tulip (Tulupa), and poppy (papaveer). In the middle and high parts of the region grow brown, glabrous, tulip and geranium. In the upper part of the area grows wheat. On the shores of the foothill valleys there are thickets. It grows willows, poplars and junipers [13].

\section{Results and discussion}

We studied the specific morphological features, mechanical composition, physical and agrochemical properties, micronutrient content, and activity of protease and urease enzymes of rainfed gray soils formed in Neogene deposits.

The color of the non-eroded soils formed in the Neogene deposits is gray-red, reddishbrown, the thickness of the humus layer is $65 \mathrm{~cm}$, the mechanical composition is heavy sandy soil; the color of the eroded soils is reddish-brown, the thickness of the humus layer is $47 \mathrm{~cm}$; The color of the soils washed away by erosion is reddish-brown, the thickness of the humus layer is $71 \mathrm{~cm}$, as well as heavy sandy and light loam soils (Table 1 and Fig. 1).

Table 1. Morphological features of rainfed gray soils formed in Neogene deposits.

\begin{tabular}{|c|c|c|c|c|c|c|c|}
\hline 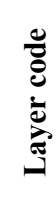 & Erodibility & Relief & Slope & 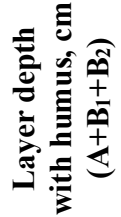 & 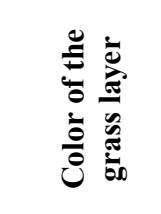 & 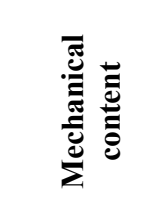 & 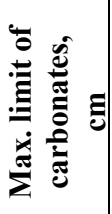 \\
\hline $\mathrm{K}_{1}$ & No erosion & Catchment & $0^{0}$ & 65 & $\begin{array}{l}\text { Gray-brown } \\
\text { reddish }\end{array}$ & $\begin{array}{l}\text { Heavy } \\
\text { sandy }\end{array}$ & 22 \\
\hline $\mathrm{K}_{2}$ & $\begin{array}{l}\text { Moderately } \\
\text { eroded }\end{array}$ & Inclined & $5^{0}$ & 47 & $\begin{array}{l}\text { Brownish- } \\
\text { red }\end{array}$ & $\begin{array}{l}\text { Heavy } \\
\text { sandy }\end{array}$ & $5-10$ \\
\hline $\mathrm{K}_{3}$ & Sedimentation & Foothill & $0.5^{0}$ & 71 & $\begin{array}{l}\text { Light } \\
\text { brownish- } \\
\text { red }\end{array}$ & $\begin{array}{c}\text { Heavy } \\
\text { sandy, } \\
\text { light clayey }\end{array}$ & 25 \\
\hline
\end{tabular}




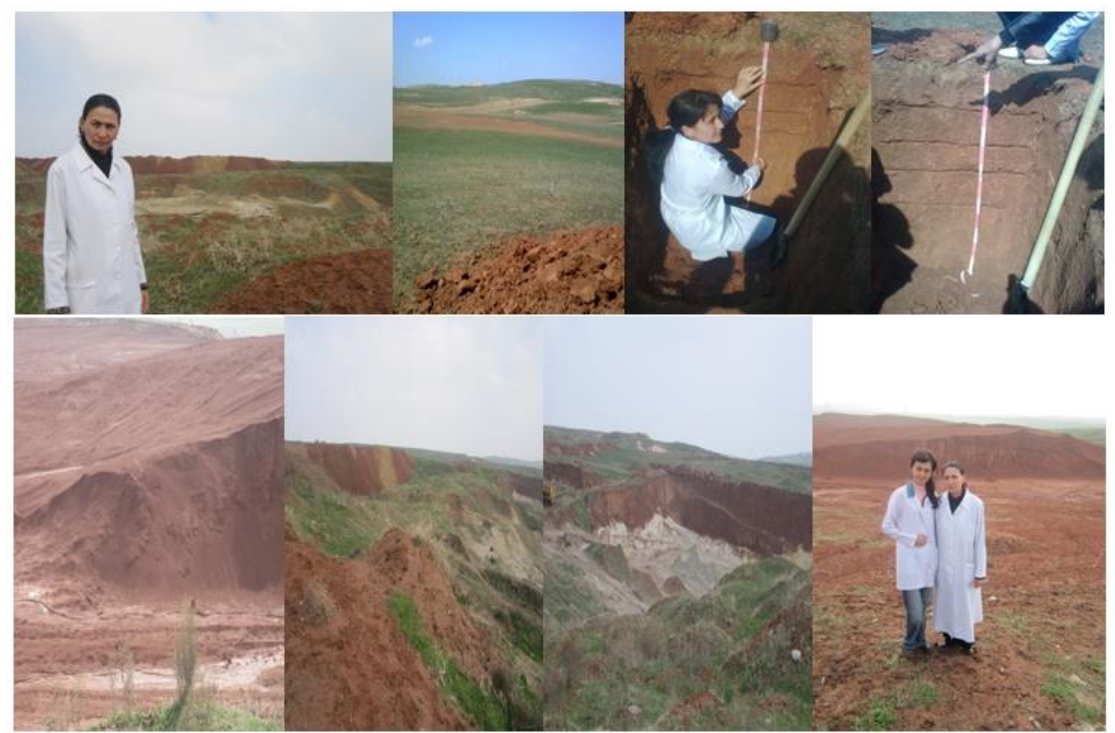

Fig. 1. Excerpts from field expeditions in May village.

The study of the physical properties and mechanical composition of the soil is a key indicator in the application of agro-technical and reclamation measures to increase soil fertility, soil mapping, and soil assessment. The mechanical composition of the soil depends on the main parameters in the characterization of the soil, namely the waterphysical, physical properties and mechanical composition, soil formation and soil-forming parent rocks. The mechanical composition of the soil varies depending on the slope on which it is spread, the degree of erosion under the influence of erosion, and the parent rock that forms the soil. Under the influence of erosion of soils located on the slopes, the degree of washing is strong, and the amount of physical mud in the upper layer of the slope is low. Under the influence of the erosion process, there is a large amount of physical mud in the washed areas. In the plains, the water washing power of the soil is low, and the non-eroded soils have the same constant mechanical composition.

The mechanical composition of rainfed gray soils formed in Neogene deposits consists of heavy sand and light loam. The mechanical composition of reddish gray soils formed in Neogene deposits is medium sand in the upper humus layers, the mechanical composition is heavier in the lower layers of the soil, the content of coarse dust $(0.05-0.01 \mathrm{~mm})$ is 29.9 $36.2 \%$, medium and the amount of fine dust $(0.01-0.001 \mathrm{~mm})$ ranges from 27.4-33.1 to $41.4 \%$. The amount of fine sand $(0.1-0.05 \mathrm{~mm})$ reaches $5.7-16.1 \%$. The amount of turbidity (less than $0.001 \mathrm{~mm}$ ) can range from $12.7-17.8$. The amount of physical sludge in the gray soils formed in the Neogene deposits is $43.3 \%$ in the upper grass layers of the section and $46.5 \%$ under the grass layer. In gray soils formed in Neogene deposits, the mechanical content is gradually increasing along the lower layers of the soil cross-section, passing from medium sand to heavy sand.

The specific gravity of rainfed gray soils formed in Neogene deposits ranges from 2.66 to $2.67 \mathrm{~g} / \mathrm{cm}^{3}$, with the lowest specific gravity occurring in the humus layer of the soil. The specific gravity increases towards the lower layers of the soil. The volumetric weight of rainfed gray soils formed in Neogene deposits is $1.35-1.40 \mathrm{~g} / \mathrm{cm}^{3}$ in the grassy layer of the soil and reaches $1.58-1.65 \mathrm{~g} / \mathrm{cm}^{3}$ in the lower layers. The porosity of gray soils formed in Neogene deposits was found to be $47.36-49.05 \%$ in the upper layers and decreased to $39.78-44.69 \%$ in the lower layers. 
Rainfed gray soils formed in Neogene deposits are distinguished by a number of their properties. The layers of soil are not well stratified, the amount of humus is small, the amount of humus can reach $1-1.5 \%$.

The thickness of the humus layer of non-eroded rainfed gray soils formed in Neogene deposits varies; soil layer thickness is low $(<40 \mathrm{~cm})$, layer thickness is moderate $(40-70 \mathrm{~cm})$ and layer thickness is high $(>70 \mathrm{~cm})$.

Hematite and limonite and manganese compounds of the iron element form a high content in the rainfed gray soils formed in the Neogene deposits, and chlorides, vermulite and amorphous substances from the minerals of the montmorrolinite group are abundant.

The humus content of non-eroded rainfed gray soils formed in the analyzed Neogene deposits is $0.89-1.11 \%$ in the upper layers and $0.46-0.58 \%$ in the lower layers, which decreases towards the lower layers. The total amount of nitrogen in the upper layers is $0.084-0.096 \%$, the amount of phosphorus is $0.112-0.123 \%$, the amount of potassium is $1.90-2.00 \%$, the amount of mobile phosphorus is $16.0-20.0 \mathrm{mg} / \mathrm{kg}$, the amount of mobile potassium is $120-140$, sometimes $-190 \mathrm{mg} / \mathrm{kg}$.

Table 2. Agrochemical properties of rainfed gray soils formed in Neogene deposits.

\begin{tabular}{|c|c|c|c|c|c|c|c|}
\hline \multirow[b]{2}{*}{ Layer code } & \multirow{2}{*}{ 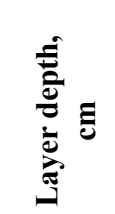 } & \multirow{2}{*}{$\begin{array}{l}\partial^{\circ} \\
\stackrel{0}{E} \\
\underline{E}\end{array}$} & \multicolumn{3}{|c|}{ Total,\% } & \multirow[b]{2}{*}{ pH } & \multirow[b]{2}{*}{$\underset{\%}{\mathrm{CO}_{2}}$} \\
\hline & & & $\mathbf{N}$ & $\mathbf{P}$ & $\mathbf{K}$ & & \\
\hline $\mathrm{K}_{1}$ & $\begin{array}{c}0-4 \\
4-20 \\
20-42 \\
42-64 \\
64-118 \\
118-175\end{array}$ & $\begin{array}{l}1.11 \\
0.89 \\
0.58 \\
0.46 \\
0.21 \\
0.11\end{array}$ & $\begin{array}{l}0.096 \\
0.084 \\
0.058 \\
0.032 \\
0.018 \\
0.010\end{array}$ & $\begin{array}{l}0.123 \\
0.112 \\
0.096 \\
0.082 \\
0.070 \\
0.054\end{array}$ & $\begin{array}{l}2.00 \\
1.90 \\
1.80 \\
1.70 \\
1.50 \\
1.30\end{array}$ & $\begin{array}{l}7.25 \\
7.30 \\
7.40 \\
7.60 \\
7.70 \\
7.75\end{array}$ & $\begin{array}{c}7.48 \\
8.12 \\
8.78 \\
9.01 \\
9.86 \\
10.21\end{array}$ \\
\hline $\mathrm{K}_{2}$ & $\begin{array}{c}0-3 \\
3-23 \\
23-43 \\
43-75 \\
75-120\end{array}$ & $\begin{array}{l}0.69 \\
0.52 \\
0.37 \\
0.24 \\
0.10\end{array}$ & $\begin{array}{l}0.075 \\
0.054 \\
0.030 \\
0.019 \\
0.012\end{array}$ & $\begin{array}{l}0.108 \\
0.092 \\
0.086 \\
0.065 \\
0.048\end{array}$ & $\begin{array}{l}1.70 \\
1.60 \\
1.50 \\
1.30 \\
1.10\end{array}$ & $\begin{array}{l}7.30 \\
7.45 \\
7.50 \\
7.60 \\
7.80\end{array}$ & $\begin{array}{c}9.57 \\
10.23 \\
10.97 \\
11.23 \\
11.67\end{array}$ \\
\hline $\mathrm{K}_{3}$ & $\begin{array}{c}0-6 \\
6-24 \\
24-42 \\
42-67 \\
67-93 \\
93-150\end{array}$ & $\begin{array}{l}1.56 \\
0.98 \\
0.72 \\
0.68 \\
0.33 \\
0.21\end{array}$ & $\begin{array}{l}0.110 \\
0.092 \\
0.076 \\
0.030 \\
0.022 \\
0.018\end{array}$ & $\begin{array}{l}0.146 \\
0.126 \\
0.118 \\
0.100 \\
0.088 \\
0.066\end{array}$ & $\begin{array}{l}2.25 \\
2.20 \\
2.00 \\
1.80 \\
1.70 \\
1.60\end{array}$ & $\begin{array}{l}7.20 \\
7.40 \\
7.45 \\
7.60 \\
7.70 \\
7.80\end{array}$ & $\begin{array}{c}7.63 \\
8.78 \\
9.87 \\
10.12 \\
11.56 \\
11.86\end{array}$ \\
\hline
\end{tabular}

The amount of humus and nutrients in the eroded reddish-gray soils formed in the studied Neogene deposits decreases sharply downwards in the soil layers. The content of $\mathrm{SO} 2$ carbonates in these soils ranges from 7.48 to $8.12 \%$, while in the lower layers this figure ranges from 9.86-10.21\%. The amount of gypsum is quite high and there is a layer of fine crystalline gypsum at a depth of $1.30-200 \mathrm{~cm}$. The soil environment reaches a $\mathrm{pH}$ of 7.25-7.75.

Humus content in rainfed gray soils formed by erosion is $0.98-1.56 \%$, gross nitrogen content is $0.092-0.110 \%$, phosphorus content is $0.126-0.146$, potassium content is 2.20 $2.25 \%, \mathrm{CO}_{2}$ carbonate content is 7.63 to $8.78 \%$, while in the lower strata this figure ranges from 11.56 to $11.86 \%$. The $\mathrm{pH}$ of the soil medium reaches $7.20-7.80$ (Table 2). 
There are a number of chemical elements in the soil that are in very small amounts and are extremely necessary, they are called microelements. Micronutrients in the soil play an important role in the growth and development of plants, and plants meet their demand for micronutrients at the expense of micronutrients in the soil. Micronutrients are enzymes necessary for plant growth and development, accelerate their biological activity, participate in oxidation-reduction processes, affect the rapid germination of seeds, prevent seed rot, play a key role in metabolism, biochemical, and biological activity in the soil and involved in photosynthesis.

From trace elements: Copper $(\mathrm{Cu})$ - Participates in the activity of protein-enzymes in plants and accelerates the germination of seeds.

Zinc $(\mathrm{Zn})$ is involved in oxidation-reduction reactions, metabolism in plant tissues, nitrogen and phosphorus metabolism in plants.

Boron (B) provides oxygen to the plant body and root in the course of biochemical processes plays a key role in biochemical processes occurring in plant organs. The effect of boron is related to oxidation-reduction processes. Plants use water-soluble compounds of boron. Soils formed in ancient marine deposits and other sedimentary deposits are much richer in the trace element Cretaceous.

Manganese (Mn) is involved in photosynthesis and acts as a catalyst in oxidationreduction reactions.

It is known from the results of the study that in the gray soils formed in the Neogene deposits in the non-eroded gray soils, Cu-content was $0.40-0.55 \mathrm{mg} / \mathrm{kg}$, followed by $\mathrm{Zn}$ content $0.20-0.25 \mathrm{mg} / \mathrm{kg}$, Mn-content $100-105 \mathrm{mg} / \mathrm{kg}$, B-content $0.50-1.28 \mathrm{mg} / \mathrm{kg}, \mathrm{Cu}$ content in moderately eroded soils is $0.30-0.35 \mathrm{mg} / \mathrm{kg}, \mathrm{Zn}$ content is $0.15-0.20 \mathrm{mg} / \mathrm{kg}, \mathrm{Mn}$ content is $70-85 \mathrm{mg} / \mathrm{kg}$, B-content is $0.69-0.50 \mathrm{mg} / \mathrm{kg}$. In the washed soils, Cu content was $0.65-0.70 \mathrm{mg} / \mathrm{kg}$, Zn content was $0.25-0.30 \mathrm{mg} / \mathrm{kg}$, Mn content was $105-115 \mathrm{mg} / \mathrm{kg}$, and Bcontent was $1.80-1.65 \mathrm{mg} / \mathrm{kg}$. It was found that in the lower layers of gray soils formed in Neogene deposits; Boron (B) trace elements are more abundant. The reason is that tertiary sediments are the oldest marine sediments, and Boron (B) is a "sea-loving" element.

The study of biological and biochemical processes of soil is important in maintaining and increasing soil fertility. Biological and biochemical processes of the soil depend on the movement of biologically active substances formed in the soil, oxidation-reduction reactions, the amount of microorganisms, which decompose as a result of decomposition of microorganisms and plant residues in it. Enzymes in the soil play a special role in the rapid development of biological and biochemical processes in the organic complex of the soil. Enzymes increase soil fertility by participating in various biochemical reactions in the soil, the decomposition of organic matter, the formation of nitrogen and humus that plants can assimilate in the soil. Enzymes are a sensitive indicator of the biological state of the soil.

The enzyme protease is an enzyme required for the formation of nitrogen in the soil and is involved in the formation of proteins and their breakdown into free amino acids.

The urease enzyme aminofication of urea and the conversion of nitrogen to a form that plants can assimilate depend on the activity of the urease enzyme. The enzyme urease is produced by a group of urobacteria in the soil. It is found in fungi, putrefactive bacteria and azotabacteria.

They studied the distribution and origin of soils formed in Neogene deposits, the composition and amount of copper and boron trace elements in the soil, the activity of the enzymes urease, phosphatase and catalase and the effect of erosion processes on them [1, 2].

Some researchers studied the morphological characteristics, mechanical composition, physical and agrochemical properties of rainfed gray soils formed in Neogene deposits, the amount of trace elements copper, zinc, Boron and manganese in reddish soils, the activity of prosthetic and urease enzymes. He studied the presence of different amounts of enzymes 
in spring and fall, the correlation of humus with enzymes, the mechanical composition of the soil with physical clay [5].

It has been found that urease enzyme levels are much lower in dry soils formed in Neogene deposits. Specifically, 3.50-4.20 mg in $1 \mathrm{~g}$ of soil in non-eroded dry soils, 2.05$2.55 \mathrm{mg}$ in $1 \mathrm{~g}$ of eroded soil, $4.00-4.85 \mathrm{mg}$ in $1 \mathrm{~g}$ of washed soil. In non-eroded soils, the urease enzyme is higher than in eroded soils. The enzyme urease decreases sharply from 50 $\mathrm{cm}$ of soil cross-section. The distribution of the urease enzyme across soil layers depends on how the process of soil formation takes place and the properties of the soil (Table 3 ).

Table 3. Enzyme activity in rainfed gray soils formed in Neogene deposits.

\begin{tabular}{|c|c|c|c|c|c|}
\hline \multirow{3}{*}{$\begin{array}{c}\text { Layer } \\
\text { code }\end{array}$} & $\begin{array}{c}\text { Layer depth, } \\
\text { cm }\end{array}$ & \multicolumn{2}{|c|}{$\begin{array}{c}\text { Protease activity in } \\
\text { tyrosine in mg per 1 g of } \\
\text { soil within 24 hours }\end{array}$} & \multicolumn{2}{c|}{$\begin{array}{c}\text { Urease activity at Ng-NH } \\
\text { in mg per 1 g of soil within } \\
\text { 24 hours }\end{array}$} \\
\cline { 2 - 6 } & & Spring & Fall & Spring & Fall \\
\hline \multirow{4}{*}{$K_{1}$} & $0-4$ & 0.127 & 0.116 & 4.20 & 3.75 \\
\cline { 2 - 6 } & $4-20$ & 0.072 & 0.060 & 3.50 & 2.10 \\
\cline { 2 - 6 } & $20-42$ & 0.055 & 0.042 & 2.50 & 1.05 \\
\cline { 2 - 6 } & $42-64$ & 0.033 & 0.028 & 1.00 & 0.67 \\
\cline { 2 - 6 } & $64-118$ & 0.022 & 0.012 & 0.30 & 0.21 \\
\cline { 2 - 6 } & $118-175$ & 0.005 & 0.003 & "footprint" & "footprint" \\
\hline \multirow{4}{*}{$\mathrm{K}_{2}$} & $0-3$ & 0.092 & 0.078 & 2.55 & 2.25 \\
\cline { 2 - 6 } & $3-23$ & 0.053 & 0.046 & 2.05 & 2.00 \\
\cline { 2 - 6 } & $23-43$ & 0.040 & 0.034 & 1.80 & 1.36 \\
\cline { 2 - 6 } & $43-75$ & 0.020 & 0.014 & 0.70 & 0.55 \\
\hline \multirow{4}{*}{$K_{3}$} & $75-120$ & 0.010 & 0.006 & "footprint" & "footprint" \\
\cline { 2 - 6 } & $0-6$ & 0.158 & 0.130 & 4.85 & 4.15 \\
\cline { 2 - 6 } & $6-24$ & 0.102 & 0.090 & 4.00 & 3.05 \\
\cline { 2 - 6 } & $24-42$ & 0.068 & 0.052 & 3.00 & 2.20 \\
\cline { 2 - 6 } & $42-67$ & 0.042 & 0.030 & 1.15 & 0.98 \\
\hline
\end{tabular}

The activity of the protease enzyme in non-eroded gray soils formed in Neogene deposits is $0.072-0.127 \mathrm{mg}$ per $1 \mathrm{~g}$ of soil in 24 hours, $0.053-0.092 \mathrm{mg}$ in $1 \mathrm{~g}$ of soil in 24 hours in moderately eroded soils, $0.102-0.158 \mathrm{mg}$ in $1 \mathrm{~g}$ of soil in 24 hours will be. In fall, it was observed to be less than in spring.

In gray soils formed in Neogene deposits, biological activity is higher in layers of soil up to $50 \mathrm{~cm}$ from the surface, and in layers of soil after $50-70 \mathrm{~cm}$; biological activity decreases sharply and is almost non-existent. Biological activity in the soil plays an important role in increasing its fertility. As a result of erosion, the activity of enzymes in the soil slows down. Urease and protease enzymes are sharply reduced and washed away in the surface layers of the soil under the influence of erosion.

It was observed that the activity of urease and protease enzymes in the soil is higher in spring than in fall. The erosion process negatively affects the activity of urease and protease enzymes, leading to a decrease in soil fertility.

\section{Conclusions}

1. Rainfed gray soils formed in the Neogene deposits in the region of gray soils are distributed in the foothills, hills, much higher part of the low mountains, and reddish dry soils formed in the Neogene deposits are distributed in the foothills, there are uneven, curved slopes. 
2. Rainfed soils are eroded to varying degrees. Erosion adversely affects the mechanical composition, physical and agrochemical properties, and biological and biochemical properties of dry soils.

3. Dry soils formed in Neogene deposits are also distinguished by morphological features. Dry soils formed in Neogene deposits are reddish in color, reddish-brown in color, high in carbonate content and alkalinity. Low in nitrogen, phosphorus, moderately supplied with potassium. The absorbing complex is characterized by an abundance of magnesium.

4. The mechanical composition of rainfed gray soils formed in Neogene deposits consists of heavy sand, light clay, dense, low porosity, high specific gravity and volume weight.

5. Low-gray soils formed in Neogene deposits have low productivity, low humus content and low nutrient content.

6. The reason for the low growth of plants on the surface of the typical gray soils formed in the Neogene deposits is that the mechanical composition of the soil is much heavier; the physical properties are compacted soils.

7. The thickness of the humus layer of rainfed gray soils formed in Neogene deposits is short and the amount of humus is much lower.

8. The activity of enzymes is high in the $30 \mathrm{~cm}$ layer of rainfed gray soils formed in Neogene deposits, the activity of protease and urease enzymes is significantly reduced in the layers below $50 \mathrm{~cm}$ of the soil layer.

\section{References}

1. M. Urmanova, A. Kuziev, D. Burkhanova, D. Kadirova, N. Namozov, N. Shadieva, E3S Web of Conferences, 244, 02036 (2021)

2. S. Islamov, N. Namozov, M. Saidova, D. Kodirova, E3S Web of Conferences, 244, 03028 (2021)

3. R.A. Kulmatov, A.A. Kist, IND. LAB, 44(12), 1689-1692 (1978)

4. V.M. Emets, R.A. Kulmatov, Doklady Biological Sciences, 271(1-6), 370-372 (1983)

5. Z. Mamatkulov, E. Safarov, R. Oymatov, I. Abdurahmanov, M. Rajapbaev, E3S Web of Conferences, 227, 03001 (2021)

6. B.Sh. Matyakubov, Z.J. Mamatkulov, R.K. Oymatov, U.N. Komilov, G.E. Eshchanova, InterCarto, InterGIS, 26, 229-239 (2020)

7. I. Mondal, S. Thakur, M. Juliev, J. Bandyopadhyay, T.K. De, Journal of Coastal Conservation, 24(4), 50 (2020)

8. V.S. Savenko, R.A. Kulmatov, Geochemistry International, 35(11), 1028-1030 (1997)

9. R. Kulmatov, J. Mirzaev, A. Taylakov, J. Abuduwaili, B. Karimov, Environmental Earth Sciences, 80(3), 122 (2021)

10. Ya.V. Peyve, Soil biochemistry, 424 (Kolos, Moscow, 1961)

11. G. Raimbaeva, Mechanical composition of typical gray soils formed in eroded Neogene deposits between the Chirchik and Keles rivers, 54 (Sharq Press, Tashkent, 1997)

12. G. Raimbaeva, Agrochemical properties of typical gray soils formed in eroded tertiary Neogene deposits of Qibray district of Tashkent province, 119 (Sharq Press, Tashkent, 1998)

13. G.Sh. Raimbaeva, Fertility elements and biochemical processes in typical serozems, 61 (Chinor Press, Tashkent, 2020) 